\title{
Plasma Analysis in Normal Green Sea Turtles, Chelonia mydas, During two Different Periods of Nesting at Ras Al- Hadd, Sultanate of Oman
}

\author{
Abdulaziz.Y.A. AlKindi, Ibrahim.Y. Mahmoudªnd Humaid Khan \\ Department of Biology, College of Science, Sultan Qaboos University, P.O.Box 36, \\ Al Khod 123, Muscat, Sultanate of Oman, ${ }^{*}$ Fulbright Senior Scholar, USA.

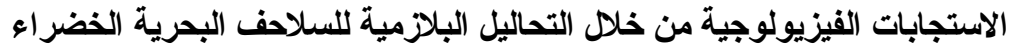

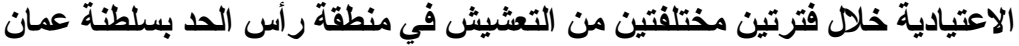 \\ عبد العزيز الكندي، ابر اهيم محمود و حميد خان

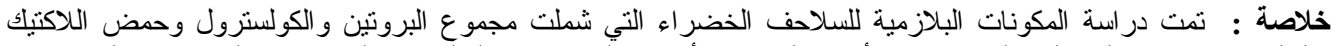

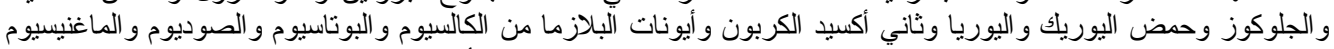

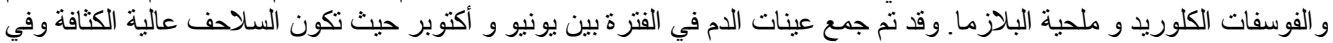

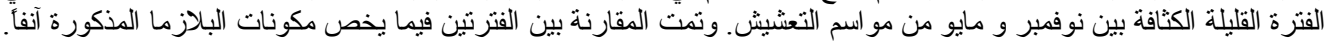

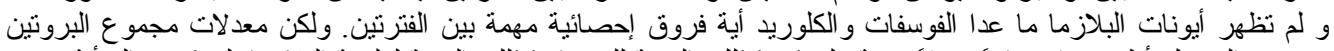

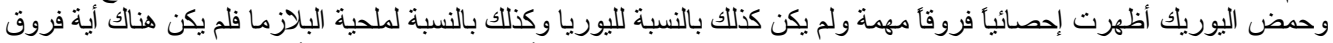

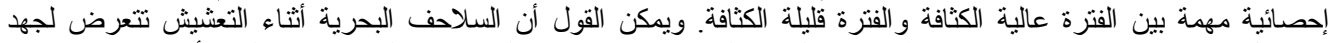

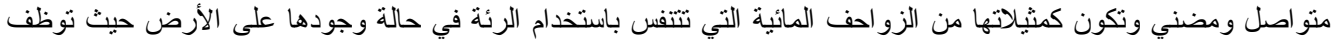

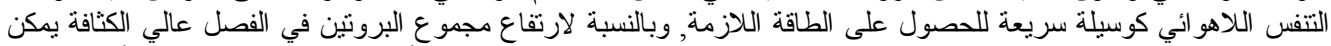

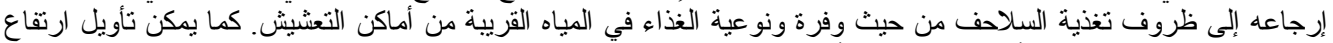

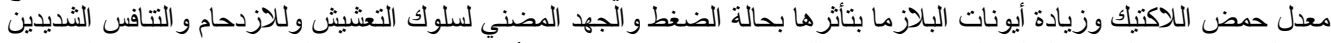

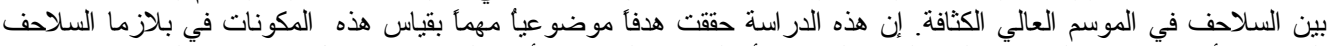

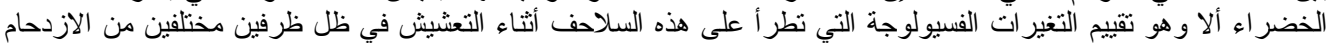

و الكثافة على مدار دورة سنوية كاملة.
\end{abstract}

ABSTRACT: Plasma composition which includes total protein, cholesterol, lactate, glucose, uric acid, urea, $\mathrm{CO}_{2}$, and electrolytes $\left(\mathrm{Ca}^{++}, \mathrm{K}^{+}, \mathrm{Na}^{+}, \mathrm{Mg}^{++}, \mathrm{PO}_{4}^{-3}, \mathrm{Cl}^{-}\right)$, and plasma osmolarity were analyzed in normal adult nesting green turtles Chelonia mydas. Blood samples were collected in June-October at the peak of the nesting season and in November-May during the non-peak period. Plasma electrolytes values, except for $\mathrm{PO}_{4}{ }^{-3}$ and $\mathrm{Cl}^{-}$were significant between the two periods. Values for total proteins and uric acid were significantly different during the two periods but urea values were insignificant. Osmolarity was unchanged during the two periods. During nesting the sea turtles undergo strenuous and exhaustive exercise and like other lung breathing reptiles, they ventilate intermittently, thus, they rely on anaerobic metabolism during the nesting exercise. Plasma concentrations of lactate and $\mathrm{CO}_{2}$ were significant but glucose values remained stable and unchanged during the two nesting periods. Higher concentrations of total protein during June compared to October may be related to the type and the availability of diet in the waters near the nesting sites. High concentrations of electrolytes and lactate are perhaps related to more stressful conditions during June because of higher crowding and intense competition for nesting sites. The aim of this study was to analyze the role of these parameters during nesting activity to evaluate changes under two different crowding conditions and gather information for future population health assessments.

KEYWORDS: Plasma Composition, Osmolarity, Nesting and Sea Turtles. 


\section{ALKINDI, MAHMOUD and KHAN}

\section{Introduction}

O smoregulation and acid-base balance are the major physiological problems that face marine turtles because the sea, which is their natural environment, is almost three times more concentrated in electrolytes than their body fluid (see Lutz, 1997). Salt influx in marine turtles is basically derived from two sources, food material such as marine algae and grasses, and swallowing large amounts of seawater during food intake (Lutz, 1997). This large salt load is counter to normal physiological functions and must be excreted as soon as it enters the body to maintain normal osmolarity and body function. The major organs, which are responsible for salt excretion, are two modified lachrymal glands with their main ducts open into the posterior canthus of each eye (Abel and Ellis, 1966; Marshall and Saddlier, 1989). These glands are responsible for about $90 \%$ of salt excretion. The rest of the body plays a minor role in reducing the salt load with approximately $5 \%$ through the cloacal chamber, and the rest excreted through the kidney and the scutes of the plastron (Lutz, 1997).

Glycogen is the main metabolic energy source of muscles which enables the turtle to synthesize glucose by gluconeogenesis, which takes place primarily in the liver. It has been suggested that carbohydrate metabolism increases because of the activation of anaerobic glycolysis (Dunn and Hochachka, 1986), which results in elevated levels of blood glucose and lactate. In fish, elevation in glucose levels could be triggered by stress (See AlKindi, et al, 2000a). In addition, blood lactate levels may also be affected by physiological stress (Pickering, et al, 1982). In a study of rainbow trout, glucose oxidation was depressed by high lactate levels, even when glucose production was stimulated by exhaustive activity. Moreover, a rise in lactate in vitro was attributed to rising lactate and $\mathrm{P}_{\mathrm{CO} 2}$, and partially to stimulatory effects of elevated catecholamine levels (Wood, et al, 1990). In reptiles, during post-exercise period, the skeletal muscle of the lizard Dipsosaurus dorsalis utilizes mainly lactate as a gluconeogenic substrate for glycogen production (Gleeson, et al, 1993). Other studies have also confirmed that skeletal muscles in lizards are capable of resynthesizing muscle glycogen in situ shortly after strenuous exercise (Gleeson, 1982, 1986, 1991; Gleeson and Dalessio, 1989, 1990). Assessment of blood chemistry in marine turtles has not been studied extensively, especially on adult marine turtles. Hasbun, et al, (1998) studied blood chemistry in adult and sub-adult green turtles caught in trawls. Other studies focused on juvenile green turtles (Aguirre, et al, 1995; Bolton and Bjorndal, 1992) and captive green turtles (Norton, et al, 1990). Lutz (1997) has recently done an extensive review on the regulation of salt, water and $\mathrm{pH}$ balance in sea turtles.

The purpose of this study is to examine the effect of nesting during peak and non-peak periods, on values of plasma electrolytes, total protein, urea, uric acid, $\mathrm{CO}_{2}$, cholesterol, glucose and lactate in normal nesting turtles. During the nesting process, the turtles undergo a sudden and stressful change which is different from the normal marine condition (AlKindi, et al, 2000b). The turtles spend several hours looking for the ideal nesting sites and during this period they have to make some physiological adjustment in the chemistry of their body fluids as well as their metabolism. Up to date, changes in the plasma parameter in nesting turtles have not been evaluated and this investigation will thoroughly monitor such changes.

\section{Methods of Investigation}

\subsection{Study area}

This investigation was conducted at Ras Al-Hadd Turtle Reserve at the Sultanate of Oman, specifically at Ras Al Junaz, along the coastal line of the Arabian Sea.

\subsection{Animals}

Normal healthy nesting green turtles without any physical defects or injuries were studied during two periods of the nesting season: June-October during peak nesting period (average 100200 turtles/night) and during non-peak nesting period November-May (average 5-10 turtles/night). 


\section{PLASMA ANALYSIS IN NORMAL GREEN SEA TURTLE, CHELONIA MYDAS}

Blood samples $(10 \mathrm{ml})$ were taken during nesting exercise with a syringe and needle from the dorsal cervical sinuses according to the method of Owen and Ruiz (1980). Several trips were made to the study area during each period for the data collection.

\subsection{Blood analysis}

The Beckman Synchron CX Systems were used to determine plasma parameters in this study. The system automatically proportions appropriate samples and reagent volumes relative to each plasma parameter.

Table 1: Methodology of analysis for blood plasma parameters using Beckman Synchron CX Systems.

\begin{tabular}{|c|c|c|c|}
\hline Methodology & Parameter & Reaction Mechanism & Detection \\
\hline Colorimetric & Protein & Endpoint Biuret & Abs (560) \\
\hline Colorimetric & Phosphate & Phosphomolybdate Blue Complex & $\mathrm{Abs}(520)$ \\
\hline Colorimetric & Magnesium & Mg-Calmagite Complex & $\mathrm{Abs}(520)$ \\
\hline Colorimetric & Calcium & Ca-Arsenazo III Complex & $\mathrm{Abs}(650)$ \\
\hline Potentiometric & Sodium & Ion Selective Electrode & Potential \\
\hline Potentiometric & Potassium & Ion Selective Electrode & Potential \\
\hline Potentiometric & Chloride & Ion Selective Electrode & Potential \\
\hline Potentiometric & $\mathrm{CO}_{2}$ & Ion Selective Electrode & Potential \\
\hline Amperometric & Glucose & Glucose oxidase production of $\mathrm{O}_{2}$ & $\Delta$ Potential \\
\hline Enzymatic & Lactate & $\begin{array}{c}\text { Lactate dehydrogenase with conversion } \\
\text { to pyruvate and the production of } \\
\text { peroxide. Peroxidase addition to } \\
\text { produce quinoneimine. }\end{array}$ & Abs(520) \\
\hline Enzymatic & Cholesterol & $\begin{array}{c}\text { Cholesterol esterase/Cholesterol } \\
\text { oxidase with production of peroxide. } \\
\text { Peroxidase addition to produce } \\
\text { quinoneimine. }\end{array}$ & Abs(520) \\
\hline Enzymatic & Urea & Urease addition to form ammonium ion. & $\Delta \mathrm{Mho}$ \\
\hline Enzymatic & Uric Acid & $\begin{array}{c}\text { Uiricase to produce allontoin and } \\
\text { hydrogen peroxide. Hydrogen peroxide } \\
\text { reacts with 4-aminoantipyrine ( 4-AAP) } \\
\text { and 3.5-dichloro-2-hydroxybenzene } \\
\text { sulfate (DCHBS) in presence of } \\
\text { peroxidase to form a quinonimine. }\end{array}$ & Abs(520) \\
\hline
\end{tabular}

Osmolarity is analyzed by measuring the freezing point of plasma using an osmometer that utilizes the depression of the freezing point of plasma and is compared to that of pure water.

\section{Results}

Total protein concentrations were significantly higher during the peak period (Figure1). Values for electrolytes $\left(\mathrm{Na}^{+}, \mathrm{K}^{+}, \mathrm{Ca}^{++}\right.$and $\left.\mathrm{Mg}^{++}\right)$were significantly higher during the peak period while $\mathrm{PO}_{4}^{-3}$ and $\mathrm{Cl}^{-}$values were not significant (Figures 2,3). Values for $\mathrm{CO}_{2}$ were found significantly higher during non-peak periods (Figure 4). Lactate values were significantly higher during the peak period, while glucose values remained stable throughout the nesting season (Figure 5). Cholesterol was significantly higher during the peak period (Figure 6). Urea values were not significant, while uric acid values were significantly higher during the peak period (Figure 7). Osmolarity concentrations remained stable throughout the nesting season (Figure 8). 


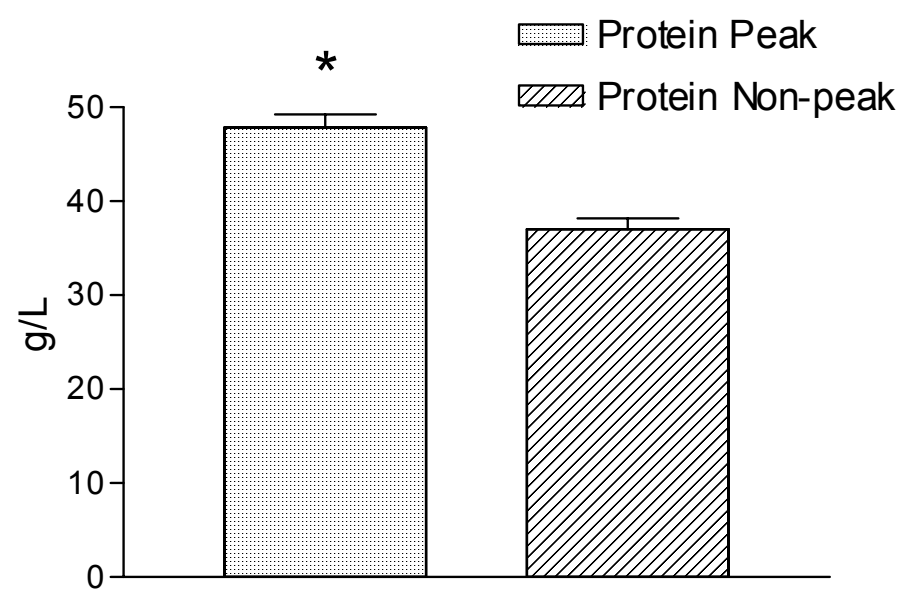

Figure 1. Mean total protein levels $( \pm \mathrm{SEM}) ;{ }^{*}=$ Significant difference.

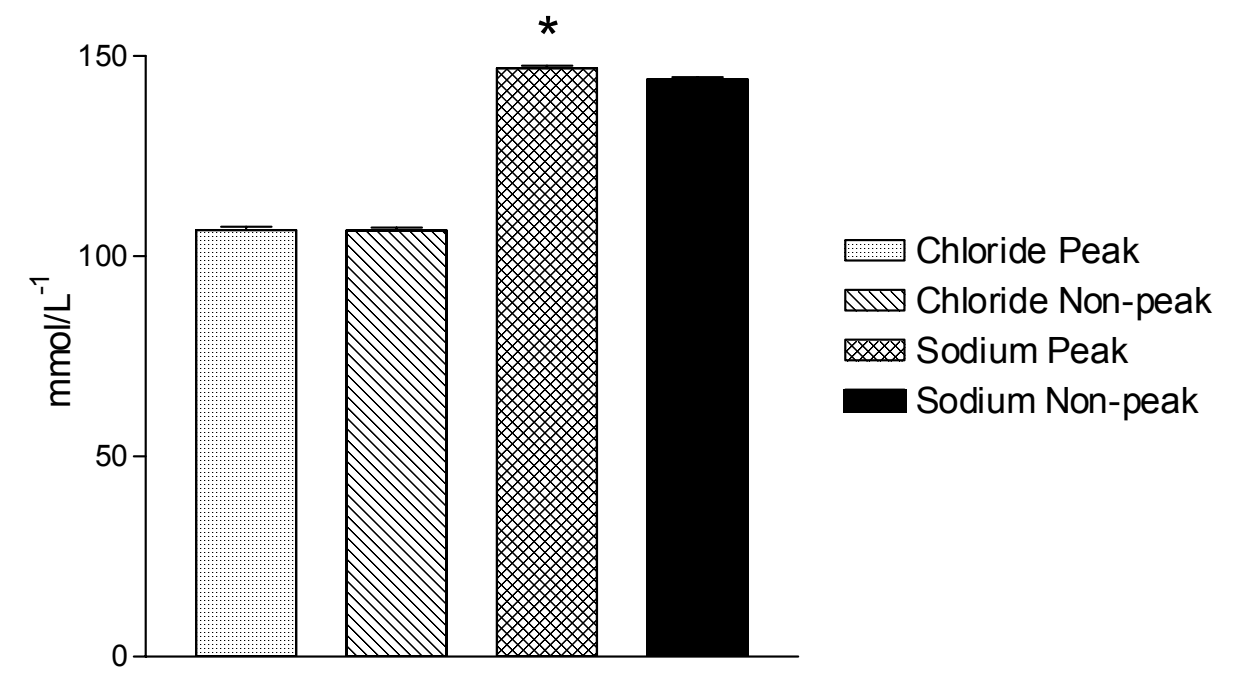

Figure 2. Mean sodium and chloride levels $( \pm \mathrm{SEM}) ; *=$ Significant difference.

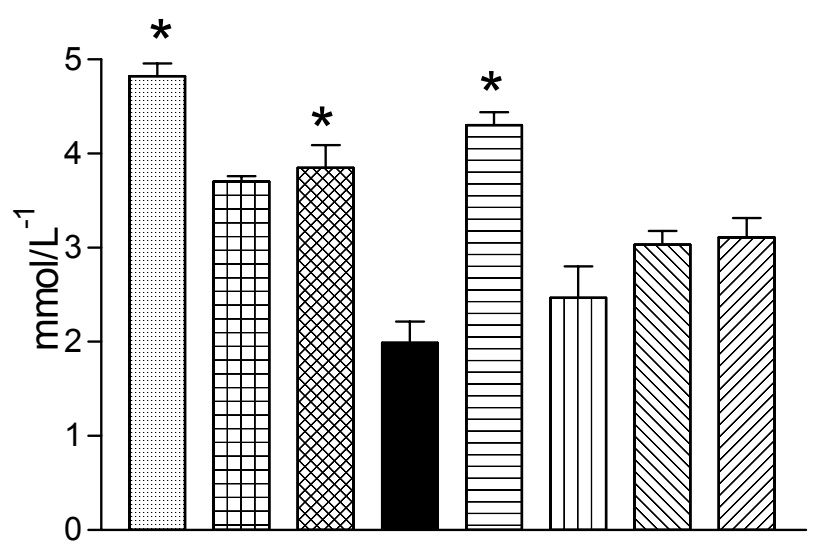

$\square$ Potassium Peak Calcium Peak Calcium Non-peak $\rightleftarrows$ Magnesium Peak Magnesium Non-Peak WU Phosphate Peak Iz]s Phosphate Non-peak

Figure 3. Mean potassium, calcium, magnesium and phosphate levels $( \pm \mathrm{SEM}),{ }^{*}=$ Significant difference. 


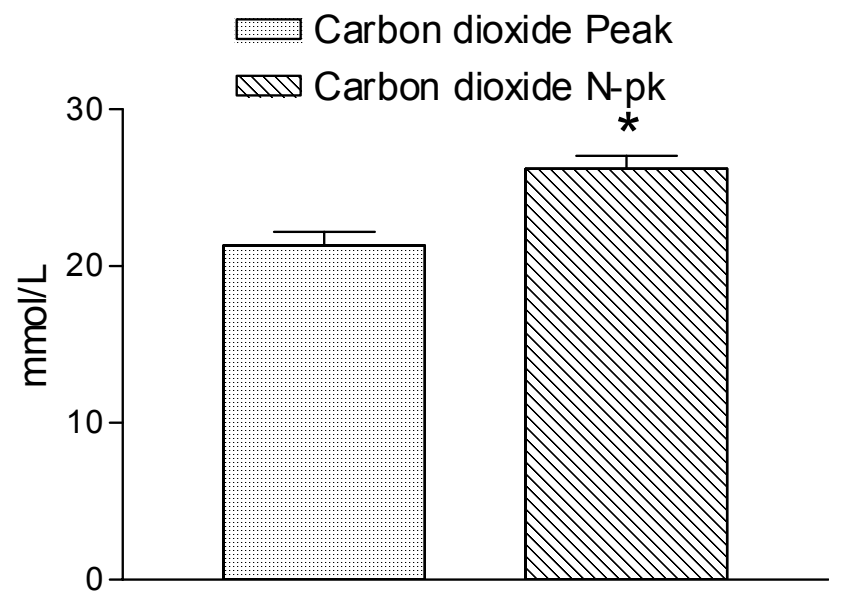

Figure 4. Mean carbon dioxide levels $( \pm \mathrm{SEM}) ;{ }^{*}=$ Significant difference.

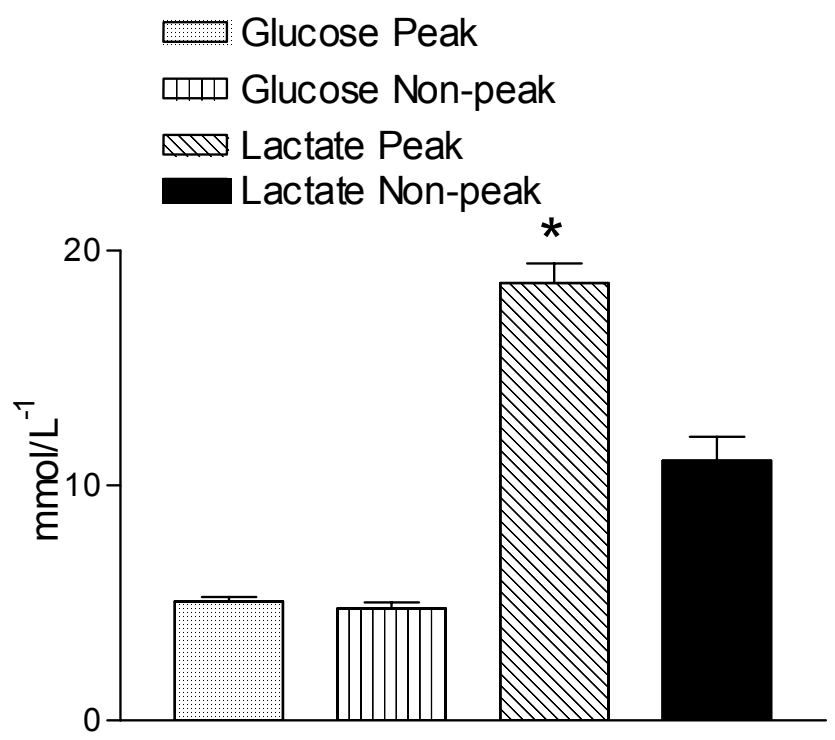

Figure 5. Mean glucose and lactate levels $( \pm \mathrm{SEM}) ;{ }^{*}=$ Significant difference.

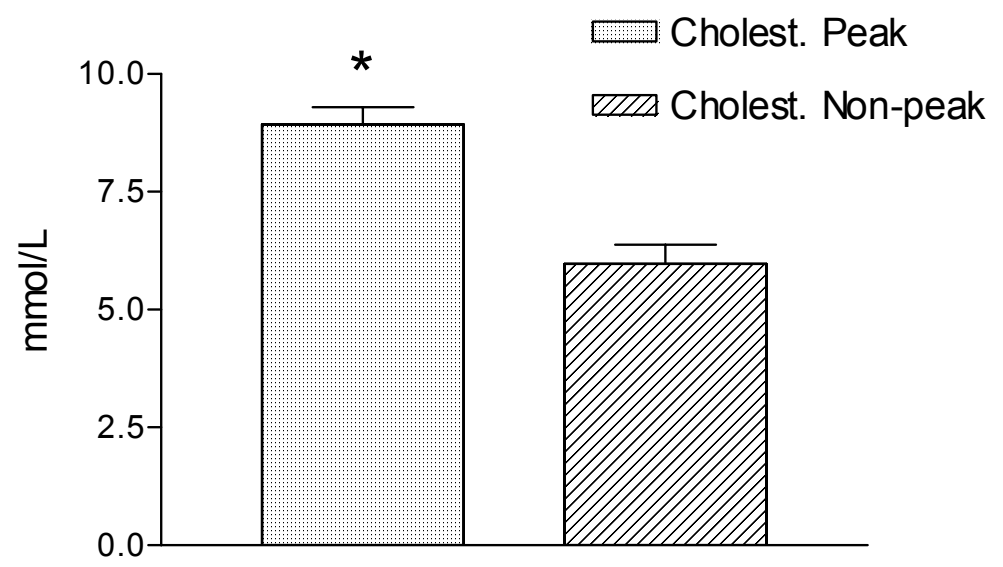

Figure 6. Mean cholesterol levels $( \pm \mathrm{SEM}) *=$ Significant difference. 


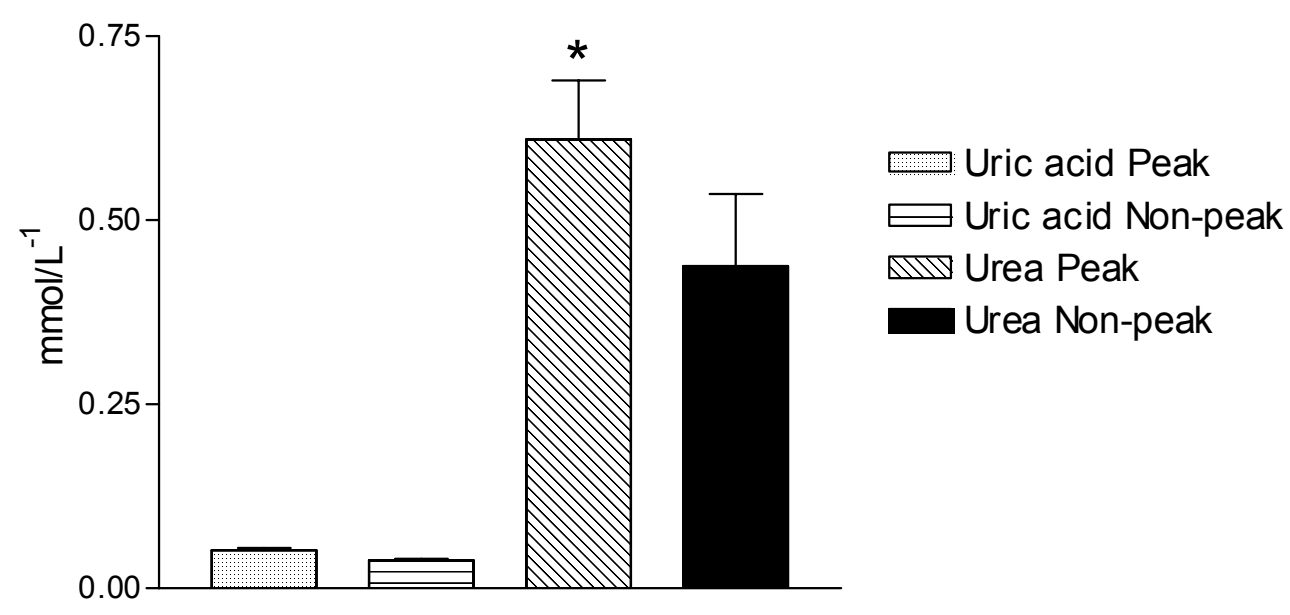

Figure 7. Mean uric acid and ammonium levels $( \pm \mathrm{SEM}) ; *=$ significant difference.

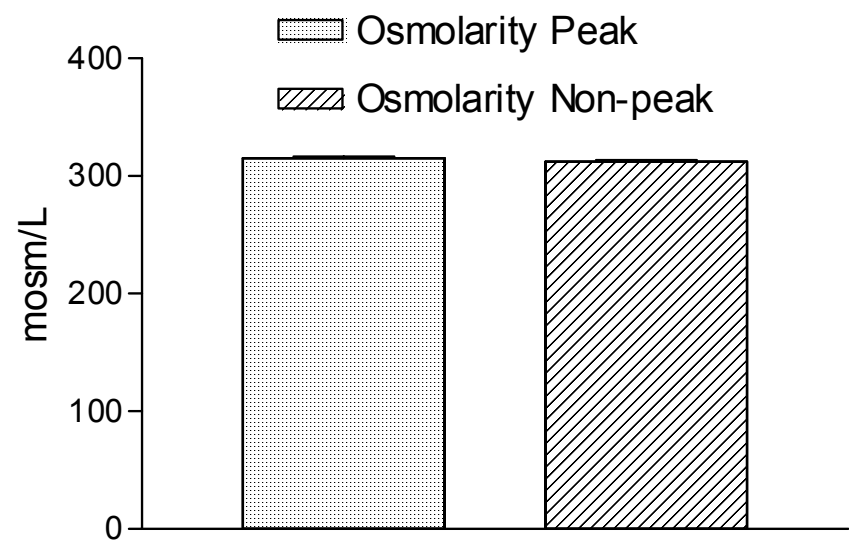

Figure 8. Mean blood osmolarity $( \pm \mathrm{SEM})$.

\section{Discussion}

The status of the blood chemistry during nesting activities has not been explored thoroughly in the past and most previous investigations dealt with turtles in their marine environment or subjected to experimental conditions (Holmes and McBean, 1964; Kooistra and Evans 1976; Bolten and Bjorndal 1992; Lutz, 1997). Marine turtles are subjected to a brief terrestrial condition encountered during their nesting exercise. This study was directed at an examination of blood chemistry during this episodic transition period of marine to terrestrial environment.

The present investigation reveals that the normal natural populations of the green turtles in Ras Al-Hadd maintain constant plasma osmolarity while they are on the nesting grounds throughout the nesting season, even though some electrolyte values differ in peak and non-peak nesting periods. We suggest that these changes are temporary and they are not detrimental to the overall health of the turtles. They appear to be capable of adjusting rapidly to normal osmotic and ionic regulatory conditions. Our field observations indicate the lachrymal glands are always active in secreting salt at the time of nesting. Furthermore, the green turtle can tolerate prolonged time from seawater to freshwater without osmotic problems (Holmes and McBean, 1964). In another investigation (Kooistra and Evans, 1976) marine turtles transferred from seawater to freshwater and after $25 \mathrm{~h}$, the turtle's orbital salt glands stopped secreting salt and after 17 days in freshwater, the efflux of 


\section{PLASMA ANALYSIS IN NORMAL GREEN SEA TURTLE, CHELONIA MYDAS}

$\mathrm{Na}$ has declined $97 \%$ and the cloaca became the major organ of secretion. These experiments provide us with some evidence that marine turtles can adjust to different sets of environmental conditions without any difficulty.

Hasbun, et al, (1998) investigated the blood chemistry of normal male and female adult and sub-adult green turtles in Ras Al-Khaimah of the United Arab Emirates during the month of May, prior to the nesting season. Blood samples were collected within an hour of capture. Although some of their blood was collected from sub-adults and some males, there were indications of close similarities with our data from the peak period. The two studies present an interesting comparison since the turtles were collected from close regions and also the blood samples from Ras AlKhaimah were collected shortly after capture, so the electrolyte values remained unchanged from the marine environment. Even though the turtles from Ras Al Hadd spent a long time on the nesting grounds under stress and exhaustive exercise, their electrolyte levels remained stable despite the change of environment.

In comparing the present electrolyte data, we find that $\mathrm{Na}^{+}, \mathrm{K}^{+}, \mathrm{Ca}^{++}$and $\mathrm{Mg}^{++}$levels were significantly higher during peak periods over non-peak periods, while $\mathrm{Cl}^{-}$and $\mathrm{PO}_{4}{ }^{-3}$ were not significantly different. The differences in values may be related to stress which has been known to change the electrolyte levels in fish (see AlKindi, et al, 2000a), or the differences could be related to individual variations at the time of sampling. During the peak period, nesting turtles are under tremendous pressure because of crowding stress, which may contribute to the rise in electrolyte levels.

Plasma electrolyte levels reported previously (Lutz and Dunbar-Cooper, 1987; Lutz, et al, 1986) were similar to the present data for $\mathrm{Na}^{+}, \mathrm{Cl}^{-}$and $\mathrm{K}^{+}$but their values for $\mathrm{Ca}^{++}$and $\mathrm{Mg}^{++}$were lower than those reported here. The high plasma $\mathrm{Ca}^{++}$levels in the present data were taken from normal nesting turtles which usually have higher $\mathrm{Ca}^{++}$levels than previous data taken from nonnesting turtles, males, or sub-adults.

Nicholson and Lutz (1989) reported that the salt glands in the green turtles maintain the same salt concentration whether loading the turtles with hypertonic $\mathrm{NaCl}$ solution or hypertonic sucrose solution. They postulated that the glands regulate salt levels by maintaining relatively constant electrolyte levels. This was attributed to their adjustment to the marine conditions. Moreover, Holmes and McBean (1964) found that $\mathrm{Na}^{+} / \mathrm{K}^{+}$ratio remains the same during the secretory activity of the glands. However, Nicholson and Lutz, (1989) reported that in the green sea turtle, there was a change in the flow rate and concentration of salt during secretion; it reached a peak and gradually declined to lower levels before dropping off to zero.

From the previous investigations, the secretory contents of inactive salt glands in the green turtle are similar to our results on plasma osmolarity. However, when these glands are active, the ionic components of the glands rise rapidly to an average of $1900 \mathrm{mOsm} / 1$, which is almost six-fold higher than the plasma level and twice that of seawater (Lutz, 1997).

In the green turtle, salt efflux is accomplished by the esophagus and the lachrymal salt glands (Lutz, 1997). The food they ingest, which consists of marine grasses and algae and the seawater they swallow during feeding are the two sources of salt load. Swallowed seawater (incidental drinking) adds a significant amount of salt load to the body. The response of the animal is immediate ejection by a powerful esophageal reverse peristalsis to force the water through the nostrils while the food material is held by closely packed conical papillae in the esophagus (Bjorndal, 1985). About $90 \%$ of salt secretion from food material takes place in the salt lachrymal glands. These two methods, which maintain normal osmolarity, are vital for the survival of marine turtles in a hostile environment.

Our data indicate that chloride and sodium are the major plasma electrolytes while the remainder of the electrolytes had lower values. Furthermore, the ratio of ionic components of salt glands and the plasma are of similar concentrations, and the plasma electrolytes in our study also maintained the same ratio of ionic concentration as that of the salt glands.

In this investigation, plasma urea levels were low during peak $(0.62 \pm 0.08 \mathrm{~m} \mathrm{~mol} / \mathrm{l})$ and nonpeak $(0.44 \pm 0.09 \mathrm{~m} \mathrm{~mol} / \mathrm{l})$ periods and there was no significant difference between the two 


\section{ALKINDI, MAHMOUD and KHAN}

periods. Urea levels from urine reported from other studies were higher than the plasma urea from this investigation. This is not surprising since plasma urea is much lower than that of the kidney. The following investigators measured urea levels in urine: Bjorndal (1979) $12.9 \mathrm{~m} \mathrm{~mol} / \mathrm{l}$; Nicholson and Lutz (1989) $8.9 \mathrm{~m} \mathrm{~mol} / \mathrm{L}$; Prange and Greenwald (1980) $2 \mathrm{~m} \mathrm{~mol} / \mathrm{L}$. The discrepancy in these values may be related to age of turtle, type of food intake and the length of time urine remains in the bladder to be subjected to reabsorption for water and ionic transport (Stetson, 1989).

Total protein plasma levels in our study and that of Bolten and Bjorndal (1992) were similar despite age or size differences. Frair and Shah (1982), on the other hand, reported that in green turtles there was a significant correlation between total protein and carapace length. Furthermore, it must be stated that the nesting turtles during peak period at Ras Al Hadd remain in the waters near the nesting grounds for at least 1.5-2 months to oviposit 3-5 clutches. During this time, the large number of turtles may consume most of the food in the area, which may have resulted in a decrease in food reserve, leading to the observed significant lower values of total protein during non-peak period.

Adjustment to the proper $\mathrm{pH}$ in the sea turtles is of an extreme importance, since they spend a great deal of time underwater depending primarily on anaerobic respiration (Wood, et al, 1984). On land, the green turtles, during nesting exercise, ventilate intermittently, depending primarily on anaerobic respiration (AlKindi, et al, 2000b). Dissociated products of lactic acid (lactic ions and $\mathrm{H}^{+}$) can cause severe acid-base disturbances and can hinder the oxygen uptake but catecholamine immediate release can facilitate oxygen uptake in most vertebrates (AlKindi, et al, 2000a). In fishes, blood osmolarity and electrolyte concentrations may be affected by stress (Aldrin, et al, 1979; AlKindi, et al, 2000a), hypoxia, certain environmental pollutants (Alkindi, et al, 1996) and osmoregularity dysfunction, which is characterized by blood electrolyte imbalance (Carmichael, et al, 1984b; AlKindi, et al, 1996; AlKindi, et al, 2000a).

Drastic changes in plasma lactate levels have also been observed in nesting green turtles at Ras Al Hadd (AlKindi, et al, 2000b). When the turtles emerge from the sea they generally go through exhaustive physical exercises during nesting phases. Before a turtle chooses its final site to lay its eggs, it frequently makes several digging attempts at several sites, with each attempt followed by abandonment. These abandonments are related to unfavorable conditions such as a lack of soil moisture and soil obstacles. Nesting is a long ordeal and usually takes between 2.5-4.5hr, sometimes longer. Under these conditions, the green turtles are subjected to a high degree of stress, evidenced by high plasma catecholamine levels during nesting exercises compared to lower levels when the green turtles first emerge from the sea (AlKindi, et al, 2000). They undergo bursts of strenuous and exhaustive forceful exercise which usually last for less than one minute followed by a recovery period lasting 10-30 seconds for deep breathing (AlKindi, unpublished data).

Under these exercise-recovery phases as shown in the present data, the turtles develop apnea accompanied by hypercapnia and acidemia associated with high-rise in $\mathrm{CO}_{2}$, which is primarily related to anaerobic metabolism. This condition persists throughout the nesting exercises as catecholamines play a major role in glycogen metabolism by stimulating glycogenolysis and/or gluconeogenesis (AlKindi, et al, 2000).

Lactate values in this study were significantly higher during the peak periods over the nonpeak periods. This may be attributed to the fact that the turtles work much harder during the peak period with higher crowding pressure and more severe competition for nesting space than during the non-peak period.

Glucose levels, however, remain stable throughout the nesting season with no significant differences observed between the two periods. The stable glucose levels may be influenced by catecholamines which stimulate glycogenolysis during nesting. Catecholamines also facilitate removal of lactate from muscles into the blood stream (AlKindi, et al, 2000b).

There is a drastic increase in plasma lactate and $\mathrm{CO}_{2}$ levels in submerged sea turtles, which is indicative of anaerobic metabolism (Lutz, 1997). Based on our data, this condition can also occur in the green turtle during the nesting process. Comparing the lactate values from both conditions 


\section{PLASMA ANALYSIS IN NORMAL GREEN SEA TURTLE, CHELONIA MYDAS}

revealed surprisingly similar results. These results indicate that sea turtles can physiologically adjust to different sets of conditions and are also frequently faced with acid-base disturbances. This condition appears to be corrected by switching to aerobic respiration to avoid acidemia and hypercapnia.

Sea turtles are known to stay submerged for a long time searching for food. For example the loggerhead sea turtles spend about $97 \%$ of their time submerged (Lutz and Bentley, 1985) which consequently leads to rapid accumulation of $\mathrm{CO}_{2}$, depletion of $\mathrm{O}_{2}$ and an acid-base disturbance. While under water, the depletion of $\mathrm{O}_{2}$ triggers anaerobic respiration resulting in accumulation of lactic acid and $\mathrm{CO}_{2}$.

Wood, et al. (1984) reported that when green sea turtles swim vigorously underwater for 15 minutes blood $\mathrm{pH}$ falls from 7.66 to 7.21 and lactate levels increases from 0.6 to $14.4 \mathrm{~m} \mathrm{~mol} / \mathrm{L}$. Plasma lactate could reach $35 \mathrm{~m} \mathrm{~mol} / \mathrm{L}$ when green turtles were forced to submerge for two hours (Hslatala, et al, 1975) while in the loggerhead, plasma lactate reached $16.2 \mathrm{~m} \mathrm{~mol} / \mathrm{L}$ after they were caught in fishing nets for 30 minutes. These values are comparable to the present data as the nesting turtles also go through vigorous exercises in short bursts while they rely mainly on anaerobic respiration.

The higher cholesterol plasma levels in the turtles from Ras Al Hadd during the summer months (peak period) may be related to the requirement for a large amount of cholesterol for the growth and maturation of the ovarian follicles. During the Fall, the cholesterol level dropped off significantly because the follicles had already attained the mature size.

Plasma profiles from natural populations of sea turtles are urgently needed so they can be used with other physiological parameters to assess the health and physiological conditions of a population (Rosskopt and Woerpel, 1982; Jacobson, et al, 1991; Bolten and Bjorndal, 1992). There is a steady decline in populations of sea turtles all over the world due to the rapid spread of pollution in marine habitats and the destruction of many feeding and nesting grounds. As a result, there is a rapid spread of diseases such as fibropapilloma reported among many geographical populations (Jacobson, et al, 1989; Balazs and Pooley, 1991). The data from this study will be used as a reference guide for future assessment of nesting populations relative to health conditions, reproductive potential and growth.

\section{Acknowledgments}

This research was supported, in part, by grant number (IG/SCI/BIOL/01/99), Deanship of Postgraduate Studies and Research, Sultan Qaboos University and by the Fulbright Program awarded to Prof. Ibrahim Younis Mahmoud, U.S.A. and by the Directorate General of Wildlife and Nature Conservation, the Ministry of Regional Municipalities and Environment of the Sultanate of Oman. Special thanks to Richard Wilbur, Public Affairs Officer, Embassy of the United States of America in Muscat, Oman and to Chris Batchelor and Helen Due Boje for their technical assistance.

\section{References}

ABEL, J.H. and ELLIS, R.A. 1966. Histochemical and electron microscope observations on the salt secreting lachrymal glands of marine turtles. Am. J. Anat. 118: 337-358.

AGUIRRE, A.A., BALAZS, G.H, SPRAKER, T.R. and GROSS T.S. 1995. Adrenal and hematological responses to stress in juvenile green turtles (Chelonia mydas) with and without fibropapillomas. Physiol. Zool. 68: 831-854.

ALDRIN, J.F., MESSAGER, J.L. and MEVEL, M. 1979. Essai sur le stress de transport chez le saumon coho juvenile salmon (Oncorhynchus kisutch). Aquaculture 17: 279-289.

ALKINDI, A.Y.A., BROWN, J.A., WARING, C.P. and COLLINS, J.E. 1996. Endocrine, osmoregulatory, respiratory and haematological parameters in flounder exposed to the water soluble fraction of crude oil. J. Fish Biol. 49: 1291-1305. 
ALKINDI, A.Y.A, BROWN, J.A. and WARING, C.P. 2000a. Endocrine, physiological and histopathological responses of fish and their larvae to stress with emphasis on exposure to crude oil and various petroleum hydrocarbons. Journal for Scientific Research. Science and Technology Special Review 2000 : 1-30.

ALKINDI, A.Y.A., MAHMOUD, I.Y. and WOLLER, M.J. 2000b. Catecholamine response in sea turtles during nesting. Abstracts, Vol 26(1) 30th Annual Meeting of the Society of Neuroscience. Abstract 143.7.

BALAZS, G.H. and POOLEY, S.G. 1991. Research plan for marine turtle fibropapilloma. National Oceanographic and Atmospheric Administration Technical Memorandum (NMFS NOAA-TM-NMFS-SWFSC-156), Honolulu, Hawaii, pp113.

BJORNDAL, K.A. 1979. Urine concentration of ammonia, urea and uric acid in the green turtle (Chelomia mydas). Comp. Biochem. Physiol. 63A: 509-510.

BJORNDAL, K.A. 1985. Nutritional ecology of sea turtles. Copeia 3: 736-751.

BOLTEN, A.B. and BJORNDAL, K.A. 1992. Blood profiles for a wild population of green turtles (Chelonia mydas) in the Southern Bahamas: size-specific and sex-specific relationships. J. Wildl. Dis. 28: 407-413.

CARMICHAEL, G.J., TOMASO, J.R., SIMCO, B.A. and DAVIS, K.B. 1984. Characterization and alleviation of stress associated with hauling large mouth bass. Trasn. Am. Fish. Soc. 113: 778-785.

DUNN, J.F. and HOCHACHKA, P.W. 1986. Meatbolic responses of trout (Salmo gairdneri) to acute environmental hypoxia. J. Exp. Biol. 123: 229-242.

FRAIR, W. and SHAH, B.K. 1982. Sea turtle blood protein concentrations correlated with carapace lengths. Comp. Biochem. Physiol. 73A: 337-339.

GLEESON, T.T. 1982. Lactate and glycogen metabolism during and after exercise in the lizard (Sceloporus occidentalis). J. Comp. Physiol. 147 B: 79-84.

GLEESON, T.T. 1986. Glycogen synthesis from lactate in skeletal muscle of the lizard (Dipsosaurus dorsalis). J. Comp. Physiol. 156: 277-283.

GLEESON, T.T. 1991. Patterns of metabolic recovery from exercise in amphibians and reptiles. J. Exp. Biol. 160: 187-207.

GLEESON, T.T. and DALESSIO, P.M. 1989. Lactate and glycogen metabolism in the lizard (Dipsosaurus dorsalis) following exhaustive exercise. J. Exp. Biol. 144: 377-393.

GLEESON, T.T. and DALESSIO, P.M. 1990. Lactate: a substrate for reptilian muscle gluconeogenesis following exhaustive exercise. J. Comp. Physiol. 160: 331-338.

GLEESSON, T.T., DALESSIO, P.M., CARR, J.A., WICKLER, S.J. and MAZZEO, R.S. 1993. Plasma catecholamine and corticosterone and their in vitro effects on lizard skeletal muscle lactate metabolism. Amer. Physiol. Soc. 34: R632-R639.

HASBUN, C.R., LAWERENCE, A.J., NALDO, J., SAMOUR, J.H. and AL-GHAIS, S.M. 1998. Normal blood chemistry of free-living green sea turtles (Chelonia mydas) from the United Arab Emirates. Comparative. Hematology International 8: 174-177.

HOLMES, W.N. and MCBEAN, R.L. 1964. Some aspects of electrolyte excretion in the green turtle (Chelonia mydas). J. Exp. Biol. 41: 81-90.

HSLATALA, M.P., STANDAERT, T.A., PIERSON, D.J., HOCHACHKA, P.W., OWEN, T.G., ALLEN, J.F. and WHITTOW G.C. 1975. Multiple end-products of anaerobiosis in diving vertebrates. Comp. Biochem. Physiol. 50B: 17.

JACOBSON, E.R., GASKIN, J.M., BROWN, M.B. HARRIS, R.K., GARDINER, C.H., LAPOINTE, J.L., ADAMS, H.P. and REGGIARDO, C. 1991. Chronic upper respiratory tract disease of free-ranging desert tortoises (Xerobates agassizii). J. Wildl. Dis. 27: 296316.

JACOBSON, E.R., MANSELL, J.K., SUNDBERG, J.P., HAJJAR, M.E., EICHMANN, L., EHRHART, L. M., WALSH, M. and MURRU, F. 1989. Cutaneous fibropapillomas of green turtle (Chelonia mydas). J. Comparative Pathol. 101: 39-52. 
PLASMA ANALYSIS IN NORMAL GREEN SEA TURTLE, CHELONIA MYDAS

KENNISH, M.J. 1994. Practical Handbook of Marine Science, 2nd ed. CRC Marine Science Series, CRC Press, Boca Raton, Fl.

KOOISTRA, T.A. and EVANS, D.H. 1976. Sodium balance in the green turtle (Chenonia mydas) in seawater and freshwater. J. Comp. Physiol. 107: 229-240.

LUTCAVAGE, M.E., LUTZ, P.L. and BAIER, H. 1987. Gas exchange in the logger head sea turtle (Caretta caretta). J. Exp. Biol. 131: 365-372.

LUTZ, P.L. 1997. Salt, water and pH balance in the sea turtle. In the Biology of Sea Turtles. Edited by P.L. Peter and J.A. Musick. CRC Press. N.W. Boca Raton, Florida, U.S.A., pp. 343-361.

LUTZ, P.L. and T.B. BENTLEY, 1985. Respiratory physiology of diving in the sea turtle Copeia. 1980(3): 671-679.

LUTZ, P.L. and DUNBAR-COOPER, A. 1987. Variations in the blood chemistry of the loggerhead sea turtle Caretta caretta. Fish Bull. 1985: 37-43.

LUTZ, P.L., LUTCAVAGE, M. and HUDSON, D. 1986. Physiological effects of oil on sea turtles, in study on the effects of oil on marine turtles. Minaral Management Service, Contract Number 14-12-0001-30063, pp 91-127.

MARSHAL. A.T. and SADDLIER, S.R. 1989. The duct system of the lachrymal gland of the green sea turtle (Chelonia mydas). Cell Tissue Res. 257: 399-404.

NICHOLSON, S.E. and LUTZ P.L. 1989. Salt gland function in the Atlantic green sea turtle. $J$. Exp. Biol. 144: 171-184.

NORTON, T.M., JACOBSON, E.R. and SUNDBERG, J.P. 1990. Cutaneous fibropapillomas and renal myxofibroma in green turtle, Chelonia mydas. J. Wild. Dis. 26: 265-270.

OWENS, D.W. and RUIZ, G.J. 1980. New methods of obtaining blood and cerebrospinal fluid from marine turtles. Herpetologica 36: 17-20.

PICKERING, A.D., POTTINGER, T.G. and CHRISTIE, P. 1982. Recovery of the brown trout (Salmo trutta L.) from acute handling stress: a time-course study. J. Fish. Biol. 20: 229244.

PRANGE, H.D. and GREENWALD, L. 1980. Effects of dehydration on the urine concentration and salt gland secretion of the green sea turtle. Comp. Biochem. Physiol. 66A: 133-136.

ROSSKOPF, W.J. Jr. and WOERPEL, R.W. 1982. The use of hematologic testing in diagnostic medicine: An introduction. Chelonian Documentation Center Newsletter 1: 30-34.

STETSON, D.L. 1989. Turtle urinary bladder: regulation of ion transport by dynamic changes in plasma membrane area. Am. J. Physiol. 257: R973-R981.

WOOD, S.C., GATZ, R. N. and GLASS, M. L., 1984. Oxygen transport in the green turtle, $J$. Comp. Physiol., 154: 275-280.

Received 30 January 2001

Accepted 17 May 2001 